DOI: $10.19195 / 0080-3626.60 .16$

RENATA PIOTROWSKA

\title{
WYKORZYSTANIE OFERTY EDUKACYJNEJ BIBLIOTEKI SZKOLNEJ PRZEZ NAUCZYCIELI PRZEDMIOTOWYCH - WYNIKI SONDAŻU
}

Współpraca nauczycieli przedmiotowych z bibliotekarzami szkolnymi i jej wpływ na rozwój umiejętności uczniów. Badanie wykorzystania potencjału biblioteki szkolnej.

SŁOWA KLUCZOWE: nauczyciel bibliotekarz, biblioteka szkolna, współpraca nauczycieli $\mathrm{z}$ bibliotekarzami, information literacy

\section{WSTĘP}

Temat współpracy pomiędzy nauczycielami a bibliotekarzami jest często podejmowany przez badaczy pochodzących ze Stanów Zjednoczonych Ameryki Północnej. Liczne dokumenty sygnowane przez American Library Association i American Association of School Librarians stanowią dla nich punkt wyjścia do teoretycznych rozważań oraz realizacji badań. W wydanych w 1988 roku wytycznych dla bibliotek szkolnych ${ }^{1}$ wskazano na wyzwania, jakie stały przed biblioteką szkolną u schyłku XX wieku. Opracowany wówczas model działania bibliotek szkolnych nie stracił na aktualności pomimo intensywnego rozwoju technologii i powszechnego dostępu do nieograniczonych zasobów informacji. Znaczącą rolę przypisano w nim bibliotekarzowi szkolnemu, który musiał sprostać zadaniu przygotowania uczniów i nauczycieli do efektywnego, krytycznego korzystania $\mathrm{z}$ informacji niezależnie od formatu, w jakim jest dystrybuowana oraz wspólnie z nauczycielami przyczyniać się do rozpoznawania i zaspokajania indywidual-

1 American Association of School Librarians; Association for Educational Communications and Technology, Information Power. Guidelines for School Library Media Programs, Chicago: American Library Association; Washington: Association for Educational Communications and Technology 1988. 
nych potrzeb uczniów ${ }^{2}$. Przypisane mu obowiązki wiązały się z byciem jednocześnie specjalistą w zakresie informacji, nauczycielem i konsultantem instruktorem. Jak zauważyła Bogumiła Staniów, owe funkcje wzajemnie się przenikały ${ }^{3}$. Ich zakres był tak rozległy, że w praktyce bibliotekarze szkolni (media specialist) mieli za zadanie organizować pracę biblioteki (School Library Media Center) tak, aby zrzeszała wszystkie osoby odpowiedzialne za proces dydaktyczny w danej szkole oraz aktywnie przyczyniała się do nawiązywania między nimi współpracy.

Wraz z rozwojem koncepcji information literacy i opracowaniem standardów, których zadaniem było systematyzowanie procesu korzystania z informacji, temat współpracy w obrębie grona pedagogicznego rozwinięto w publikacji Information Power. Building partnerships for learning $(1998)^{4}$. W myśl idei information literacy zagadnienia współpracy grona pedagogicznego omówiono w niej jeszcze bardziej szczegółowo, albowiem celem dokumentu było wskazanie na bibliotekę szkolną jako idealne miejsce służące do kształcenia kompetencji informacyjnych. Sukces w tym zakresie warunkowany był odpowiednim podejściem nauczycieli, którzy musieli współpracować z bibliotekarzem, aby zaproponowane standardy mogły być w pełni realizowane 5 .

Skrupulatne omówienie potrzeby współpracy oraz zasad jej podejmowania było odpowiedzią na dotychczasowe nieodzwierciedlenie założeń teoretycznych w praktyce szkolnej. W świetle wyników badań nauczyciele przedmiotowi nie postrzegali bibliotekarzy jako osób, z którymi należy współpracować w trakcie projektowania procesu kształcenia. Pokutował stereotypowy wizerunek biblioteki będącej miejscem wypożyczania lektur. Kay Bishop i Nancy Larimer, autorki artykułu Literacy through Collaboration ${ }^{6}$, odpowiedzialnością za taki stan rzeczy obarczyły bibliotekarzy, a jego zmianę badaczki uzależniały od większego zaangażowania się tej grupy zawodowej w planowanie i przygotowywanie zajęć przez nauczycieli. Wskazywały, że pomocne w tym względzie byłoby wzajemne wymienianie się pomysłami przez bibliotekarzy szkolnych ${ }^{7}$.

Zalecenia autorstwa amerykańskich stowarzyszeń bibliotekarskich poświęcone organizacji działalności bibliotek szkolnych oraz wyniki badań wskazujące na korzyści płynące ze współpracy grona pedagogicznego przyczyniły się do

2 Ibidem, s. 1.

3 Bogumiła STANIÓW, Rola bibliotekarza szkolnego w nowoczesnej bibliotece szkolnej w USA, Biblioteka w Szkole 1997, nr 2, s. 1.

4 American Association of School Librarians; Association for Educational Communications and Technology, Informaton Power. Building partnership for learning, Chicago-London: American Library Association 1998.

5 Ibidem, s. 51.

${ }^{6}$ Kay BISHOP, Nancy LARIMER, Literacy through Collaboration, Teacher Librarian (27) 1999, nr 1, s. 15-20.

7 Za: Shayne RUSSELL, Eric DIGEST, Teachers and Librarians: Collaborative Relationships, Teacher Librarian (29) 2002, nr 5, s. 8-11. 
wzrostu znaczenia bibliotek szkolnych w procesie nauczania. Obrazuje to między innymi usytuowanie biblioteki w centralnym miejscu szkoły i wydzielanie w niej pomieszczeń o przeznaczeniu dydaktycznym.

W Polsce pedagogiczną rolę biblioteki szkolnej już w okresie międzywojennym podkreślała Helena Radlińska. Postulowała, aby pracownicy bibliotek włączali się z proces dydaktyczny i aktywnie wykorzystywali go do popularyzowania czytelnictwa $^{8}$. W późniejszym okresie Emilia Białkowska wskazywała natomiast na usługową funkcję biblioteki szkolnej w stosunku do realizowanych programów nauczania9. Te z kolei w większości nie sygnalizowały nauczycielom skorzystania z proponowanych przez nią zasobów czy usług. Wyjątek stanowiły programy nauczania języka polskiego obowiązujące od początku lat 60 . do połowy lat 80 . $\mathrm{XX}$ wieku ${ }^{10}$. Zakładały one współpracę polonistów z bibliotekarzami w szkole podstawowej i średniej w zakresie realizacji wskazanych tematów. Jednak Ministerstwo Oświaty nie regulowało zasad współdziałania, pozostawiając tym samym nauczycielom i bibliotekarzom dowolność w tym względzie, co w poszczególnych szkołach mogło skutkować całkowitym pominięciem bibliotekarza w procesie dydaktycznym bądź scedowaniem na niego obowiązku realizowania zagadnień wskazanych w programach nauczania. Tryb i zakres włączania się bibliotekarzy w proces nauczania uregulował Program przysposobienia czytelniczego i informacyjnego ${ }^{11}$. Określał on czas oraz tematy, za których realizację odpowiedzialni byli nauczyciele bibliotekarze, a także wskazywał, że pozostali nauczyciele powinni egzekwować od uczniów wiadomości i umiejętności nabyte podczas tych zajęć. Jednak programy nauczania innych przedmiotów nie odnosiły się tak jednoznacznie do współpracy w tym zakresie. Wyjątek stanowił język polski. Analiza programów nauczania języka polskiego oraz przysposobienia czytelniczego i informacyjnego dowodzi, że pokrywały się w nich niektóre zagadnienia. Zabieg ten jeszcze bardziej podkreślił konieczność współpracy między polonistami a bibliotekarzami szkolnymi. Warto zwrócić uwagę, że zgodnie z treściami programów nauczania poloniści byli jedynymi przedstawicielami nauczycieli przedmioto-

${ }^{8}$ Zob. Helena RADLIŃSKA (pseud. H. Orsza), Zadania bibljoteki szkolnej, Warszawa: M. Arct 1927.

9 Emilia BIAŁKOWSKA, Praca pedagogiczna z czytelnikami w bibliotece szkolnej, Warszawa: SBP 1964, s. 10.

10 Program nauczania w szkole podstawowej, Warszawa 1959; Program nauczania ośmioklasowej szkoly podstawowej (tymczasowy). Język polski: klasy V-VIII, Warszawa: Państwowe Zakłady Wydawnictw Szkolnych 1964; Program nauczania ośmioklasowej szkoły podstawowej. Język polski: klasy 5-8, Warszawa: Państwowe Zakłady Wydawnictw Szkolnych 1974; Program nauczania liceum ogólnoksztatcacego. Język polski: klasy I-IV, Warszawa: Państwowe Zakłady Wydawnictw Szkolnych 1974.

11 Program szkoty podstawowej. Przysposobienie czytelnicze i informacyjne, Warszawa: Wydawnictwa Szkolne i Pedagogiczne 1983; Przysposobienie czytelnicze i informacyjne. Program liceum ogólnoksztatcacego oraz liceum zawodowego i technikum, Warszawa: Wydawnictwa Szkolne i Pedagogiczne 1985. 
wych, którym jednoznacznie polecono realizację celów tożsamych z zaleceniami dla nauczycieli bibliotekarzy.

Przydzielenie bibliotekarzom zajęć dydaktycznych podniosło jednocześnie prestiż wykonywanej przez nich pracy. Zbiegło się to $\mathrm{z}$ wejściem w życie zarządzenia Ministra Oświaty i Wychowania z dnia 13 maja 1983 roku w sprawie programu pracy bibliotek szkolnych w resorcie oświaty i wychowania ${ }^{12}$, którego załącznik stanowił Program pracy biblioteki szkolnej. Zawarte w nim zalecenia potęgowały konieczność nawiązywania współpracy nauczycieli z bibliotekarzami szkolnymi. Głównie miała ona polegać na wykorzystywaniu biblioteki jako interdyscyplinarnej pracowni szkolnej oraz przygotowywaniu uczniów do korzystania z informacji oraz do samokształcenia ${ }^{13}$. Mimo jego nieobligatoryjności od przeszło dwudziestu lat w literaturze naukowej wciąż pojawiają się odniesienia do sformułowanych w nim zasad i metod działania bibliotek szkolnych ${ }^{14}$. Pominięcie w 1993 roku zarządzenia w wykazie obowiązujących resortowych aktów prawnych ${ }^{15}$ zapoczątkowało poważne zmiany w bibliotekarstwie szkolnym.

Reforma edukacji przeprowadzona w 1999 roku poskutkowała wieloma poważnymi zmianami w organizacji procesu nauczania, które dotknęły również nauczycieli bibliotekarzy. Realizowany przez nich do 1999 roku program przysposobienia czytelniczego i informacyjnego został zastąpiony ścieżką międzyprzedmiotową - edukacja czytelnicza i medialna. Idea łączenia kształcenia umiejętności wyszukiwania informacji z różnych źródeł, ich oceniania, selekcjonowania, przetwarzania, prezentowania $\mathrm{w}$ różnorodnych formach wpisywała się $\mathrm{w}$ nurt przygotowania uczniów do kształcenia ustawicznego, jednak problematyczne okazało się wcielenie jej w pracę zawodową nauczycieli. Według sondażu przeprowadzonego przez Bogumiłę Staniów w 2006 roku najczęstszym wymaganiem stawianym uczniom było wyszukiwanie informacji w trakcie zajęć lekcyjnych głównie ze źródeł drukowanych. Nie skupiano się na kształceniu pozostałych umiejętności przypisanych edukacji czytelniczej i medialnej. Wręcz świadomie pomijano niektóre, wychodząc z założenia, że uczniowie nabędą je na zajęciach $\mathrm{z}$ innego przedmiotu ${ }^{16}$. Niesystemowe podejście nauczycieli było sprzeczne z założeniami reformy. Projekt współdziałania nauczycieli, synchronicznej realizacji tematów zajęć, które dawałyby uczniom możliwość holistycznego poznawania świata, nie przyniósł zamierzonego sukcesu. Upatrywano w nim nadzieję na

12 Dziennik Urzędowy Ministerstwa Oświaty i Wychowania 1983, nr 5, poz. 30-31.

13 Marcin DRZEWIECKI, Biblioteka we wspótczesnej szkole, Warszawa: SBP 1991, s. 36.

14 Zob. Mariola ANTCZAK, Rola bibliotek i bibliotekarzy szkolnych w edukacji spoteczeństwa informacyjnego na tle przeobrażeń oświatowych w Polsce w latach 1989-2007, Łódź: Wydaw. Uniwersytetu Łódzkiego 2010; Danuta SANIEWSKA et al., Vademecum wspótczesnego nauczyciela bibliotekarza, Warszawa: Agencja Sukurs 2011; B. STANIÓW, Biblioteka szkolna dzisiaj, Warszawa: SBP 2012.

15 Dziennik Urzędowy Ministerstwa Edukacji Narodowej 1993, nr 3, poz. 9.

16 B. STANIÓW, Każdy sobie rzepkę skrobie, czyli o realizacji edukacji czytelniczej, informacyjnej i medialnej w szkole: wyniki sondażu, Biblioteka w Szkole 2006, nr 12, s. 3-6. 
podejmowanie współpracy w obrębie nauczycieli w danej szkole, jednak koncentracja na konieczności „przerobienia” materiału nie pozostawiała im czasu na twórcze włączanie treści ścieżek do realizowanych zajęć. Przyczyny takiego podejścia mogły wynikać z trudności, które przez Hannę Batorowską zostały sklasyfikowane jako subiektywne, albowiem wiążą się one z błędnym rozumieniem kultury informacyjnej jedynie jako umiejętności wyszukiwania informacji lub utożsamiania umiejętności informacyjnych z nauką korzystania z komputera. Znamienny dla nauczycieli przedmiotowych jest również brak świadomości, w jaki sposób w procesie dydaktycznym mogliby wykorzystać potencjał biblioteki szkolnej ${ }^{17}$. W takiej atmosferze bibliotekarze, nawet jako koordynatorzy ścieżki „Edukacja czytelnicza i medialna”, nie mieli wystarczających możliwości uczestniczenia w procesie dydaktycznym. Brak współpracy grona pedagogicznego na tym polu pociągał za sobą konsekwencje w postaci niedostatecznego przygotowania uczniów do poruszania się w świecie mediów i przekazywanej za ich pomocą informacji.

Wbrew pojawiającym się postulatom przywrócenia oddzielnego przedmiotu poświęconego kształceniu kompetencji medialnych i informacyjnych ${ }^{18}$, nowelizacja rozporządzenia Ministra Edukacji Narodowej z dnia 15 lutego 1999 roku w sprawie podstawy programowej kształcenia ogólnego w 2008 roku poskutkowała likwidacją ścieżek międzyprzedmiotowych, przyporządkowując ich treści konkretnym przedmiotom. Jednocześnie polecono nauczycielom wszystkich przedmiotów „wykorzystywanie zbiorów biblioteki szkolnej w procesie dydaktycznym oraz nawiązywanie współpracy z nauczycielem bibliotekarzem w celu wszechstronnego przygotowania uczniów do samokształcenia i świadomego wyszukiwania, selekcjonowania i wykorzystywania informacji"19.

Mimo iż odstąpiono od jednoznacznego wyznaczania bibliotekarzom szkolnym konkretnych obowiązków, nie pominięto ich udziału w procesie kształcenia. Zważywszy na wszechstronność oferty edukacyjnej biblioteki szkolnej, ich obecność wydaje się wręcz niezbędna. Katarzyna Materska zaznacza, że składa się na nią udostępniana przestrzeń, źródła oraz zbiory, kształcenie kompetencji czytelniczych, medialnych i informacyjnych, a także rozwijanie osobowości i aktywności społecznej uczniów ${ }^{20}$. Dlatego też podjęte przez autorkę niniejszego artykułu badania miały na celu sprawdzenie, czy nauczyciele wybranych przedmiotów wy-

17 Hanna BATOROWSKA, Kultura informacyjna $w$ perspektywie zmian w edukacji, Warszawa: SBP 2009, s. 345.

18 M. ANTCZAK, op. cit., s. 64.

19 Rozporządzenie Ministra Edukacji Narodowej z dnia 27 sierpnia 2012 r. w sprawie podstawy programowej wychowania przedszkolnego oraz kształcenia ogólnego w poszczególnych typach szkół, Dziennik Ustaw Rzeczpospolitej Polskiej 2012 poz. 977.

${ }^{20}$ Katarzyna MATERSKA, Różnorodność przestrzeni edukacyjnej bibliotek: na przykładach bibliotek amerykańskich i skandynawskich, [w:] Biblioteka w przestrzeni edukacyjnej. Funkcje $i$ wyzwania w XXI wieku. Red. Stanisław Skórka, Kraków: Wydaw. Naukowe Uniwersytetu Pedagogicznego 2013, s. 122. 
korzystują potencjał biblioteki szkolnej zgodnie z ministerialnymi zaleceniami. Jednocześnie miały na celu ustalenie, czy rodzaj nauczanego przedmiotu wiąże się z korzystaniem z oferty edukacyjnej biblioteki szkolnej.

\section{MATERIAŁY I METODY}

Badanie przeprowadzono w drugiej połowie 2015 roku. Zastosowano metodę sondażu diagnostycznego, wybraną techniką badań była ankieta, której autorski kwestionariusz został przygotowany na potrzeby niniejszej pracy. Narzędzie przetestowano w badaniu pilotażowym na grupie dwunastu nauczycieli ze szkół podstawowych i gimnazjalnych powiatu wrocławskiego. Dążąc do uzyskania jak największej liczby odpowiedzi, kwestionariusz opracowano w wersji tradycyjnej i elektronicznej w serwisie Survio.pl. Ankieta adresowana była wyłącznie do nauczycieli wybranych przedmiotów. Wśród nich znaleźli się: nauczyciele klas 1-3, języka polskiego, historii (historia i społeczeństwo - II etap edukacji) oraz nauczyciele przedmiotów przyrodniczych (przyroda - II etap kształcenia i biologia - III i b IV etap kształcenia). Badaniem objęto nauczycieli ze szkół podstawowych, gimnazjalnych i ponadgimnazjalnych z terenu całej Polski. Doboru dokonano w sposób losowy. Korzystając $\mathrm{z}$ baz danych grupujących szkoły według typó ${ }^{21}$ oraz generatora liczb losowych ${ }^{22}$, z każdego etapu kształcenia wyłoniono trzydzieści placówek. Informacja o badaniu oraz ankieta w formie drukowanej zostały rozesłane do wylosowanych szkół. Jednocześnie pocztą elektroniczną przesłano dyrektorom szkół link do elektronicznej wersji ankiety z prośbą o udostępnienie go nauczycielom wskazanych przedmiotów. Udział w badaniu był dobrowolny.

Kwestionariusz składał się z 16 pytań. Kafeterie wymagały udzielenia jednej lub kilku odpowiedzi. Dodatkowo ankietowani mieli możliwość udzielenia własnej odpowiedzi. W pytaniach wykorzystano również trzystopniową skalę pomiarową. Uzyskane wyniki badań poddano analizie statystycznej. Do oceny istnienia zależności między analizowanymi zmiennymi użyto testu chi-kwadrat. $\mathrm{W}$ badaniach przyjęto $5 \%$ błąd wnioskowania i związany z nim poziom istotności $p<0,05$, wskazujący na zależności istotne statystycznie ${ }^{23}$. Na ankietę odpowiedziało 252 nauczycieli, z czego do badania zakwalifikowano 244. Pozostałe kwestionariusze zostały odrzucone ze względu na niekompletność udzielonych odpowiedzi.

21 Wykaz szkół i placówek według typów. System Informacji Oświatowej, http://www.cie. men.gov.pl/index.php/sio-wykaz-szkol-i-placowek/27-wykaz-wg-typow.html [dostęp: 20 V 2016].

22 Generator liczb losowych, http://www.losowe.pl/.

23 Statystyczny drogowskaz 1. Praktyczne wprowadzenie do wnioskowania statystycznego. Pod red. Sylwii Bedyńskiej i Marzeny Cypriańskiej, Warszawa: Wyższa Szkoła Psychologii Społecznej 2013, s. 137. 


\section{WYNIKI BADAŃ}

Zbliżona liczba (po mniej więcej 90) respondentów jako swoje miejsce pracy wskazała szkołę podstawową lub ponadgimnazjalną, przy czym warto zaznaczyć, że ponad połowę nauczycieli ze szkół podstawowych stanowili nauczyciele klas 1-3. Największą liczbę odpowiedzi odnotowano od nauczycieli języka polskiego (90). Z kolei najmniej kwestionariuszy zostało odesłanych przez nauczycieli przyrody i bibliologii (41) (tab. 1).

Tab. 1. Liczba nauczycieli, którzy wzięli udział w badaniu, z podziałem na ich przynależność do szkoły oraz przedmioty, których uczyli

\begin{tabular}{|l|l|c|c|c|c|}
\hline \multicolumn{1}{|c|}{ Przedmiot } & $\begin{array}{c}\text { Szkoła } \\
\text { podstawowa }\end{array}$ & Gimnazjum & $\begin{array}{c}\text { Szkoła po- } \\
\text { nadgimna- } \\
\text { zjalna }\end{array}$ & $\begin{array}{c}\text { Liczba nauczycieli } \\
\text { według przedmio- } \\
\text { tów, których uczą }\end{array}$ \\
\hline \multirow{2}{*}{$\begin{array}{l}\text { Edukacja wczes- } \\
\text { noszkolna }\end{array}$} & dane liczbowe & 55 & - & - & 55 \\
\cline { 2 - 6 } & dane procentowe & $100 \%$ & - & - & $100 \%$ \\
\hline \multirow{2}{*}{ Język polski } & dane liczbowe & 18 & 31 & 41 & 90 \\
\cline { 2 - 6 } & dane procentowe & $20 \%$ & $34 \%$ & $45 \%$ & $100 \%$ \\
\hline $\begin{array}{l}\text { Przedmioty } \\
\text { historyczne }\end{array}$ & dane liczbowe & 10 & 17 & 31 & 58 \\
\cline { 2 - 6 } & dane procentowe & $17,24 \%$ & $29,31 \%$ & $53,45 \%$ & $100 \%$ \\
\hline $\begin{array}{l}\text { Przedmioty } \\
\text { przyrodnicze }\end{array}$ & dane liczbowe & 11 & 10 & 20 & 41 \\
\cline { 2 - 6 } & dane procentowe & $26,83 \%$ & $24,39 \%$ & $48,78 \%$ & $100 \%$ \\
\hline $\begin{array}{l}\text { Liczba nauczy- } \\
\text { cieli z poszcze- } \\
\text { gólnych szkó1 }\end{array}$ & dane liczbowe & 94 & 58 & 92 & 244 \\
\cline { 2 - 6 } & dane procentowe & $38,52 \%$ & $23,77 \%$ & $37,70 \%$ & $100 \%$ \\
\hline
\end{tabular}

Źródło: badania własne, 2015.

Ponad $80 \%$ respondentów oceniło ofertę edukacyjną biblioteki szkolnej jako wystarczającą. Opozycyjne zdanie wypowiedziało blisko 16\% ankietowanych. Najbardziej krytyczni okazali się nauczyciele przedmiotów historycznych, najmniej natomiast nauczyciele języka polskiego (wykres 1).

Na pytanie, czy w trakcie prowadzonych zajęć wykorzystują ofertę edukacyjną biblioteki szkolnej do ich urozmaicenia bądź uzupełnienia, blisko 95\% nauczycieli $(n=244)$ odpowiedziała twierdząco. Wśród czternastu przeczących odpowiedzi połowę stanowił głos nauczycieli historii. Kolejno negatywnie wypowiedzieli się nauczyciele języka polskiego i przedmiotów przyrodniczych. Mimo to $\mathrm{w}$ gronie nauczycieli deklarujących korzystanie z biblioteki ci pierwsi mieli największy udział procentowy (36,96\%). W badanej grupie wszyscy nauczyciele klas 1-3 potwierdzili korzystanie z oferty edukacyjnej biblioteki szkolnej. 


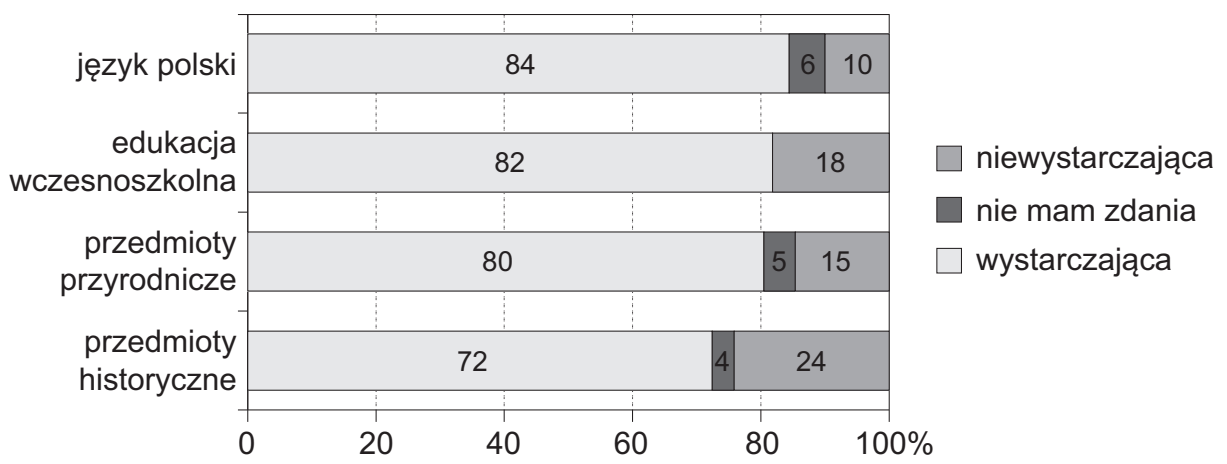

Wykres 1. Oferta edukacyjna biblioteki szkolnej w ocenie nauczycieli wybranych przedmiotów

Źródło: badania własne, 2015.

Niewiele ponad połowa respondentów przyznała, że zdarzyło się im zaproponować bibliotekarzowi szkolnemu temat zajęć, który uzupełniałby realizowany przez nich program. Przeszło połowę tej grupy stanowili nauczyciele języka polskiego. Spośród nich $(n=90)$ blisko dwie trzecie deklarowało zgłaszanie bibliotekarzowi potrzeby rozszerzenia oferty edukacyjnej. Większość odpowiedzi twierdzących udzielili również nauczyciele edukacji wczesnoszkolnej. Rozkład odpowiedzi pozytywnych i negatywnych był odmienny w wypadku nauczycieli przedmiotów historycznych i przyrodniczych, którzy znacznie częściej wybierali korzystanie z gotowych propozycji.

Ankietowani, którzy deklarowali zgłaszanie bibliotekarzowi szkolnemu konieczności rozszerzenia oferty edukacyjnej $(n=123)$, zostali poproszeni o ocenę

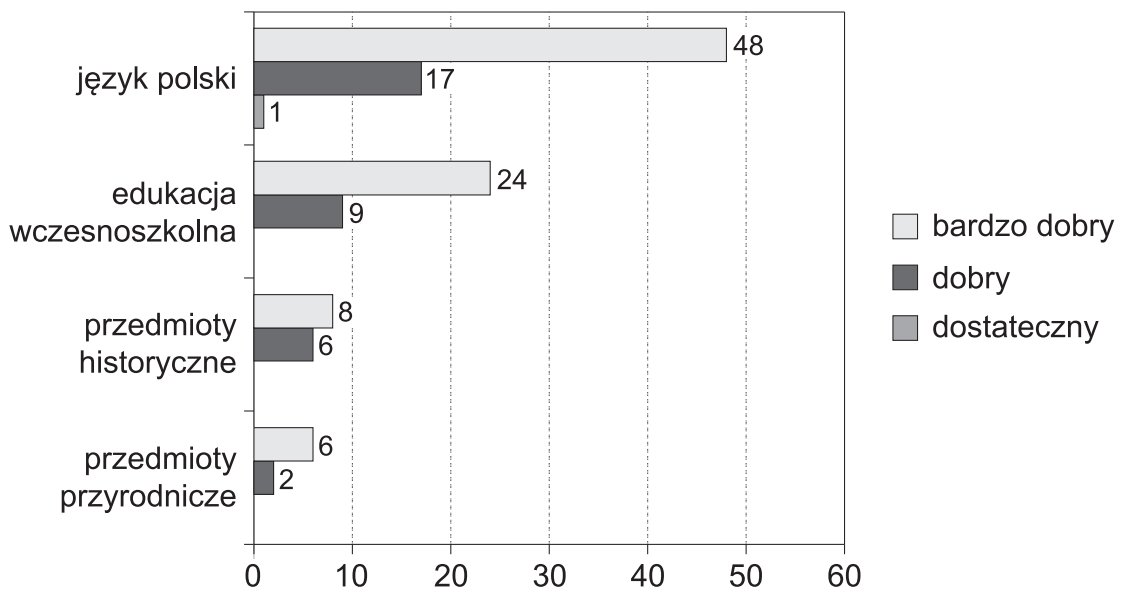

Wykres 2. Poziom zajęć przygotowywanych przez nauczyciela bibliotekarza w opinii nauczycieli

Źródło: badania własne, 2015. 
poziomu przygotowanych przez niego zajęć. W opinii większości efekty pracy bibliotekarza można było ocenić jako bardzo dobre lub dobre. Na tle nauczycieli pozostałych przedmiotów poloniści okazali się najbardziej krytyczni (wykres 2).

Na pytanie, czy zdarzyło się respondentom wspólnie z bibliotekarzem szkolnym przygotować zajęcia poświęcone konkretnemu tematowi, uzyskano jeszcze mniej twierdzących odpowiedzi. Przeszło $60 \%$ badanych nauczycieli nie angażuje się w organizowanie i wspólne prowadzenie zajęć z nauczycielem bibliotekarzem. W porównaniu do poprzedniego pytania odpowiedzi udzielone przez nauczycieli

Tab. 2. Wykorzystanie oferty edukacyjnej biblioteki szkolnej przez nauczycieli wybranych przedmiotów oraz ich współpraca z bibliotekarzem szkolnym

\begin{tabular}{|c|c|c|c|c|c|c|}
\hline \multirow[b]{2}{*}{ przedmiot } & \multicolumn{2}{|c|}{$\begin{array}{l}\text { Wykorzystywanie oferty } \\
\text { edukacyjnej biblioteki } \\
\text { szkolnej do urozmai- } \\
\text { cenia lub uzupełnienia } \\
\text { prowadzonych zajęć }\end{array}$} & \multicolumn{2}{|c|}{$\begin{array}{l}\text { Proponowanie biblio- } \\
\text { tekarzowi szkolnemu } \\
\text { tematów zajęć, które } \\
\text { uzupełniałyby realizo- } \\
\text { wany program? }\end{array}$} & \multicolumn{2}{|c|}{$\begin{array}{c}\text { Przygotowywanie i rea- } \\
\text { lizowanie zajęć wspólnie } \\
\text { z bibliotekarzem szkol- } \\
\text { nym }\end{array}$} \\
\hline & Tak & Nie & Tak & Nie & Tak & Nie \\
\hline \multirow{4}{*}{$\begin{array}{l}\text { Edukacja } \\
\text { wczesno- } \\
\text { szkolna } \\
\text { n=55 }\end{array}$} & 55 & 0 & 34 & 21 & 24 & 31 \\
\hline & $100,00 \%$ & $0 \%$ & $61,82 \%$ & $38,18 \%$ & $43,64 \%$ & $56,36 \%$ \\
\hline & $23,91 \%$ & $0 \%$ & $27,64 \%$ & $17,36 \%$ & $26,97 \%$ & $20,00 \%$ \\
\hline & $22,54 \%$ & $0 \%$ & $13,93 \%$ & $8,61 \%$ & $9,84 \%$ & $12,70 \%$ \\
\hline \multirow{4}{*}{$\begin{array}{l}\text { Język } \\
\text { polski } \\
\text { n=90 }\end{array}$} & 85 & 5 & 67 & 23 & 41 & 49 \\
\hline & $94,44 \%$ & $5,56 \%$ & $74,44 \%$ & $25,56 \%$ & $45,56 \%$ & $54,44 \%$ \\
\hline & $36,96 \%$ & $35,71 \%$ & $54,47 \%$ & $19,01 \%$ & $46,07 \%$ & $31,61 \%$ \\
\hline & $34,84 \%$ & $2,05 \%$ & $27,46 \%$ & $9,43 \%$ & $16,80 \%$ & $20,08 \%$ \\
\hline \multirow{4}{*}{$\begin{array}{l}\text { Przed- } \\
\text { mioty } \\
\text { historycz- } \\
\text { ne } \\
\mathrm{n}=58\end{array}$} & 51 & 7 & 14 & 44 & 15 & 43 \\
\hline & $87,93 \%$ & $12,07 \%$ & $24,14 \%$ & $75,86 \%$ & $25,86 \%$ & $74,14 \%$ \\
\hline & $22,17 \%$ & $50,00 \%$ & $11,38 \%$ & $36,36 \%$ & $16,85 \%$ & $27,74 \%$ \\
\hline & $20,90 \%$ & $2,87 \%$ & $5,74 \%$ & $18,03 \%$ & $6,15 \%$ & $17,62 \%$ \\
\hline \multirow{4}{*}{$\begin{array}{l}\text { Przed- } \\
\text { mioty } \\
\text { przyrod- } \\
\text { nicze } \\
n=41\end{array}$} & 39 & 2 & 8 & 33 & 9 & 32 \\
\hline & $95,12 \%$ & $4,88 \%$ & $19,51 \%$ & $80,49 \%$ & $21,95 \%$ & $78,05 \%$ \\
\hline & $16,96 \%$ & $14,29 \%$ & $6,50 \%$ & $27,27 \%$ & $10,11 \%$ & $20,65 \%$ \\
\hline & $15,98 \%$ &, $82 \%$ & $3,28 \%$ & $13,52 \%$ & $3,69 \%$ & $13,11 \%$ \\
\hline \multirow{4}{*}{$\begin{array}{l}\text { Suma } \\
N=\mathbf{2 4 0}\end{array}$} & 230 & 14 & 123 & 121 & 89 & 155 \\
\hline & $94,26 \%$ & $5,74 \%$ & $50,41 \%$ & $49,59 \%$ & $36,48 \%$ & $63,52 \%$ \\
\hline & $100,00 \%$ & $100,00 \%$ & $100,00 \%$ & $100,00 \%$ & $100,00 \%$ & $100,00 \%$ \\
\hline & $94,26 \%$ & $5,74 \%$ & $50,41 \%$ & $49,59 \%$ & $36,48 \%$ & $63,52 \%$ \\
\hline
\end{tabular}

Źródło: badania własne, 2015. 
historii i przedmiotów przyrodniczych niewiele się różnią. Spadek liczby odpowiedzi pozytywnych odnotowano natomiast w grupie polonistów i nauczycieli edukacji wczesnoszkolnej. Niemniej jednak wśród badanych nauczyciele języka polskiego wciąż stanowią najliczniejszą grupę najaktywniej współpracującą z bibliotekarzem szkolnym (tab. 2).

Na podstawie wartości testu chi-kwadrat można przyjąć, że rodzaj nauczanego przedmiotu wiąże się z wykorzystywaniem oferty edukacyjnej biblioteki szkolnej $\left(\chi^{2}(3,244)=7,71 ; p<0,05\right)$, proponowaniem jej rozszerzenia $\left(\chi^{2}(3,244)\right.$ $=55,33 ; p<0,000)$ i podejmowaniem przez nauczycieli współpracy z nauczycielem bibliotekarzem $\left(\chi^{2}(3,244)=10,97 ; p<0,012\right)$. Wymienione aktywności statystycznie istotnie częściej podejmowali nauczyciele języka polskiego niż nauczyciele przedmiotów, które zostały uwzględnione w badaniu.

\section{WNIOSKI}

Uzyskane wyniki wskazują na prawidłowość częstszego podejmowania współpracy z bibliotekarzem szkolnym przez polonistów niż przez nauczycieli innych przedmiotów. Jednak sama częstotliwość wykorzystywania oferty edukacyjnej biblioteki w trakcie zajęć lekcyjnych w celu ich uzupełnienia lub urozmaicenia może budzić pewne kontrowersje. Ze względu na małą liczebność obserwacji w niektórych z badanych grup wynik testu chi-kwadrat może nie być do końca wiarygodny. Celem weryfikacji wskazane byłoby powtórzenie badania z uwzględnieniem większej pod względem liczebności próby.

Częsty kontakt nauczycieli języka polskiego z bibliotekarzem, skutkujący podejmowaniem wspólnych inicjatyw, może być uwarunkowany historycznie i wynikać z tradycji polskiej szkoły. Analiza programów nauczania obowiązujących na terenie Polski w drugiej połowie XX wieku wykazała, że poloniści mieli obowiązek podejmować z uczniami tematy z zakresu tworzenia bibliografii, rozwijania czytelnictwa czy samokształcenia ${ }^{24}$. Mogli w tym celu korzystać z pomocy bibliotekarzy szkolnych. Analogiczne rozwiązanie zaproponowano na mocy reformy oświaty przeprowadzonej w 1999 roku. Idea ścieżek międzyprzedmiotowych przyświecała włączaniu się wszystkich nauczycieli do ich realizacji, a zatem do podejmowania współpracy. W czasie ich obowiązywania próbę ustalenia stopnia współpracy nauczycieli bibliotekarzy między innymi z gronem pedagogicznym podjęła Mariola Antczak, analizując wizerunek bibliotekarzy szkolnych w opinii nauczycieli i uczniów. Uzyskane wyniki pokazały, że w większości jakość tej współpracy była oceniana jako bardzo dobra, rzadziej — średnia. Jedynie nielicz-

${ }^{24}$ Renata PIOTROWSKA, Edukacja informacyjna w polskiej szkole, Warszawa: Wydaw. SBP 2011, s. 53-68. 
ni zaznaczyli jej brak ${ }^{25}$. Niestety, badani nauczyciele nie zostali rozróżnieni pod względem reprezentowanej dziedziny wiedzy. Nie uwzględniono też przedmiotu i formy owej współpracy. Jednocześnie badaczka w swojej pracy wskazała na marginalizowanie roli biblioteki szkolnej na skutek niedostatecznego wykorzystania potencjału nauczycieli bibliotekarzy w procesie dydaktycznym.

Nauczyciele badani przez Hannę Batorowską nie postrzegali bibliotekarza szkolnego jako równego sobie. Część z nich utożsamiała jego zadania z podejmowaniem zastępstw za nieobecnych kolegów i koleżanki czy realizacją treści ścieżki edukacji czytelniczej i medialnej. Ankietowani nauczyciele nie byli zgodni co do obowiązków spoczywających na nich oraz na bibliotekarzu szkolnym. Blisko połowa uważała, że bibliotekarz jest odpowiedzialny za wychowanie informacyjne uczniów. Tyle samo było przeciwników tego sądu ${ }^{26}$.

Brak jednomyślności w środowisku nauczycieli i najwyraźniej brak wiedzy na temat własnych obowiązków i możliwości ich realizowania nie jest dobrym punktem wyjścia do nawiązywania współpracy z bibliotekarzem szkolnym. Marginalizowanie jego roli w procesie dydaktycznym może mieć negatywny wpływ na poziom kompetencji czytelniczych, medialnych i informacyjnych uczniów. Brak świadomości nauczycieli o znaczeniu tych umiejętności w XXI wieku wydaje się mało prawdopodobny. Zdecydowana większość ankietowanych potwierdziła zainteresowanie ofertą edukacyjną biblioteki szkolnej i wykorzystywanie propozycji nauczyciela-bibliotekarza w celu wzbogacania swoich zajęć. Ponadto badania przeprowadzane w ostatnich latach dowodzą, że coraz więcej nauczycieli korzysta $z$ technologii informacyjno-komunikacyjnej podczas przygotowywania się do lekcji, a także w jej trakcie. Przyznają co prawda, że nie wykorzystują w pełni ich potencjału, jednak nie stoją na stanowisku, że nie warto doskonalić się w tym zakresie ${ }^{27}$.

Niezwykle istotnym czynnikiem wpływającym na wynik badania współpracy nauczycieli przedmiotowych z bibliotekarzem szkolnym może być ich stosunek do podejmowania współdziałania w swoim środowisku. Kontynuując badania, warto byłoby zwrócić uwagę na bariery wpływające na taki stan rzeczy. Konieczne byłoby również uściślenie, jakie formy przybiera współpraca na linii nauczyciel przedmiotowy i nauczyciel-bibliotekarz. Jednocześnie stworzenie nauczycielom możliwości wypowiedzenia się na temat ich oczekiwań względem biblioteki i bibliotekarza szkolnego mogłoby wyznaczyć kierunek zmian i doprowadzić do poprawy komunikacji między nimi.

${ }^{25}$ M. ANTCZAK, op. cit., s. 212-213.

${ }^{26}$ H. BATOROWSKA, op. cit., s. 424.

27 Jak nowe technologie pomagaja uczyć? Wyniki badań Edunews.pl wśród nauczycieli polskich szkót, http://www.edunews.pl/images/pdf/jak_nowe_tech_pomagaja.pdf [dostęp: 20 V 2016]. 
RENATA PIOTROWSKA

\title{
USE OF EDUCATIONAL RESOURCES OF SCHOOL LIBRARIES BY TEACHERS OF VARIOUS SUBJECTS - RESULTS OF A SURVEY
}

\begin{abstract}
Summary
The author of the paper discusses cooperation between teachers of various subjects and school librarians. She stresses that from the point of view of developing information literacy, such cooperation translates into development of the pupils' skills. She points to the recommendations of American librarian societies in this respect (Information Power. Guidelines for School Library Media Programs and Information Power. Building partnerships for learning) as well as Polish ministerial recommendations (annex to Rozporzadzenie Ministra Edukacji Narodowej z 27 sierpnia 2012 r.w sprawie podstawy programowej wychowania przedszkolnego oraz ksztatcenia ogólnego w poszczególnych typach szkół [Regulation of the Minister of National Education of 27 August 2012 on the core curriculum for kindergartens and general education in various types of schools]). At the same time the author's analysis of the curricula for various subjects in Poland in the second half of the 20th century demonstrates that the problem was marginalised (with the exception of Polish language curricula). The aim of the author's study was to establish whether teachers of selected subjects used the potential of school libraries in line with the ministerial recommendations. In addition, the author was looking for a link between the type of the subject taught at school and use of educational resources of the school library. The author discusses the results of her diagnostic survey $(\mathrm{N}=244)$. The statistical conclusions are based on the results of chisquared tests. The results show unequivocally that teachers of Polish are statistically more likely, than teachers of other subjects included in the study, to use the educational resources of the school library, to suggest that they should be expanded and to collaborate with the librarian.
\end{abstract}

KEY WORDS: librarian teacher, school library, cooperation between teachers and librarians, information literacy 